\title{
Determinan Kesehatan Ibu Hamil Tentang Tanda Bahaya Kehamilan dengan Pencapaian Kontak Minimal 4 Kali Selama Masa Kehamilan (K4)
}

\author{
Katmini $^{1 *}$ \\ ${ }^{1}$ Program Studi Kesehatan Masyarakat, Institut Ilmu Kesehatan Strada Indonesia, Kediri \\ *Email : katminitini@gmail.com
}

\begin{abstract}
Background: Danger sign of pregnancy was a sign that someone who pregnant have a serious problem with the mother or fetus. Contact at least 4 times during pregnancy $(K 4)$ was the fourth contact of pregnant women with the medical employee (or more), to obtain antenatal care according to established standards, provided that at least one contact in the first trimester, one contact on the second trimester and two contact times in the third trimester. The purpose of this study was to determine the correlation between knowledge pregnant women about the danger signs of pregnancy with the achievement of K4.Methods: The research method was using analytical research design type of cross sectional correlation. The subjects in this study was the entire third trimester pregnant women in the Selopanggung Village Semen District Regency of Kediri as many as 12 people, sampling technique using saturation sampling and research in March until April 2019. Measuring instrument used was questionnaire and book KIA. Data analysis was using Fisher Probability Exact Test. Results: The results showed all third trimester pregnant women have a good knowledge (100\%) and as much as $33 \%$ of pregnant women can achieve K4. The analysis showed that the calculated $p$ value was 1 greater than 0.01 so there wasn't correlation between knowledge pregnant women about the danger signs of pregnancy with the achievement of K4. Conclusion: This research was expected to increase further enhance the achievement of $K 4$ by medical employee with home visit.
\end{abstract}

Keywords: knowledge, danger sign of pregnancy, achievement $K 4$

\section{PENDAHULUAN}

Kehamilan adalah kondisi dimana seorang wanita memiliki janin yang sedang tumbuh di dalam tubuhnya (yang pada umumnya di dalam rahim). Kehamilan pada manusia berkisar 40 minggu atau 9 bulan, dihitung dari awal periode menstruasi terakhir sampai melahirkan. Kehamilan merupakan suatu proses reproduksi yang perlu perawatan khusus, agar dapat berlangsung dengan baik kehamilan mengandung kehidupan ibu maupun janin. Resiko kehamilan ini bersifat dinamis, karena ibu hamil yang pada mulanya normal, secara tiba-tiba dapat berisiko tinggi (Maternity dan Putri, 2017).

Pelayanan antenatal merupakan pelayanan kesehatan yang diberikan oleh tenaga kesehatan yang profesional untuk meningkatkan derajat kesehatan ibu hamil beserta janin yang dikandungnya. Standar pelayanan antenatal meliputi timbang berat badan, pengukuran tinggi badan, tekanan darah, nilai status gizi (ukur lingkar lengan atas), tinggi fundus uteri, menentukan presentasi janin dan denyut jantung janin, skrining status imunisasi tetanus dan memberikan tetanus toxoid (TT) bila diperlukan, pemberian tablet zat besi minimal 90 tablet selama kehamilan, test laboratorium (rutin dan khusus), tatalaksana kasus, serta temu wicara (konseling), termasuk Perencanaan Persalinan dan Pencegahan komplikasi $(\mathrm{P} 4 \mathrm{~K})$, serta keluarga berencana pasca persalinan (Marniyati et al, 2016).

Pada umumnya kehamilan berkembang dengan normal dan menghasilkan kelahiran bayi sehat cukup bulan melalui jalan lahir, namun ini kadang tidak sesuai 
dengan yang diharapkan. Sulit sekali diketahui sebelumnya bahwa kehamilan akan menjadi masalah. Oleh karena itu pelayanan antenatal atau asuhan antenatal merupakan cara penting untuk memonitor dan mendukung kesehatan ibu hamil normal dan mendeteksi ibu dengan kehamilan normal (Kementerian Kesehatan RI, 2016).

Masalah pengawasan kehamilan merupakan bagian terpenting dari seluruh rangkaian perawatan ibu hamil. Melalui pengawasan tersebut dapat ditetapkan kesehatan ibu hamil, kesehatan janin, dan hubungan keduanya sehingga dapat direncanakan pertolongan persalinan yang tepat. Sehingga ibu harus mengetahui tentang bahaya-bahaya kehamilan yang dapat terjadi (Rukiyah, 2014).

Kurangnya pengetahuan tentang bahaya kehamilan dapat menyebab kematian maternalk antara lain perdarahan (25\%), infeksi (15\%), aborsi yang tidak aman (13\%), eklampsia (12\%), persalinan yang buruk (8\%), penyebab obstetrik langsung lainnya (8\%), dan penyebab tidak langsung (20\%) (WHO,2016). Beberapa penyebabkan kematian maternal tersebut disebabkan adanya komplikasi yang dapat muncul melalui tanda bahaya kehamilan.

Pengetahuan tanda bahaya kehamilan dinilai melalui beberapa komponen antara lain konsep tanda bahaya, perdarahan vagina, edema, demam tinggi, penurunan gerak janin, muntah persisten, dan ruptur membran (Nugroho et al, 2017). Ibu hamil perlu mengetahui tanda bahaya kehamilan karena munculnya tanda bahaya dapat menjadi indikasi adanya kemungkinan bahaya pada kehamilan yang dapat berdampak buruk pada kesehatan ibu hamil dan janin (Nuraisya, 2018).
Cakupan K4 di Jawa Timur tahun 2017 mencapai 576.297 ibu hamil atau $88,07 \%$. Angka ini meningkat dibandingkan tahun 2016 sebesar 85,90\%, namun belum dapat mencapai target nasional 90\%. Berdasarkan data Dinas Kesehatan Kabupaten Kediri tahun 2018 cakupan K4 mencapai 90,9\% dan cakupan K4 terendah adalah di Kecamatan Semen sebesar $80,5 \%$ dengan pencapaian terendah adalah di Desa Selopanggung yaitu dari 76 sasaran ibu hamil jumlah pencapaian K4 sebesar 53 ibu hamil.

Berdasarkan Laporan Kematian Ibu (LKI) Kabupaten/Kota se Jawa Timur tahun 2018 sebesar 228 per 100.000 kelahiran hidup. Angka tersebut masih jauh dari target sebesar 101,4 per 100.000 kelahiran hidup, maka kondisi tersebut menunjukkan keberhasilan Provinsi Jawa Timur dalam menekan kematian ibu. Jumlah Kematian Maternal di Provinsi Jawa Timur berdasarkan laporan Kematian Ibu Kab/Kota pada tahun 2018 tercatat sebanyak 598 kasus kematian dengan rincian 152 kematian masa hamil, 163 waktu bersalin dan 283 pada masa nifas. Pada penelitian Fadiar (2018) dengan responnden berjumlah 96 orang menunjukkan bahwa memiliki pengetahuan tinggi mengenai tanda bahaya kehamilan dan memiliki perilaku yang kurang tepat dalam merawat kehamilan

Penyebab langsung kematian ibu antara lain perdarahan, eklampsia, partus lama, komplikasi aborsi dan infeksi (Kementrian Kesehatan RI, 2016). Sementara itu yang menjadi penyebab tak langsung kematian ibu adalah "Empat Terlambat" dan "Empat Terlalu" (Profil Jawa Timur, 2017). 
Bahaya kehamilan dapat di cegah oleh ibu dengan berkonsultasi dengan bidan setempat ataupun dokter kandungan. Guna melakukan terapi atau treatment lainnya yang tidak membahaya kan ibu dan bayi. Penelitian Ritsma (2018) bahwa salah satu yang dapat mencegah bahaya kehamilan dengan melakukan yoga, hasil penelitian menunjukkan bahwa yoga yang dilakukan pada trimester III memberikan dampak yang sangat baik bagi ibu dan anak sehingga dapat mencegah bahaya kehamilan

Berdasarkan latar belakang di atas peneliti tertarik untuk melakukan penelitian tentang "Hubungan Pengetahuan Ibu Hamil Tentang Tanda Bahaya Kehamilan Dengan Pencapaian K4 Di Desa Selopanggung Kecamatan Semen".

Tujuan penelitian ini adalah mengetahui hubungan pengetahuan ibu hamil tentang tanda bahaya kehamilan dengan pencapaian K4 di Desa Selopanggung Kecamatan Semen Kabupaten Kediri.

\section{METODE PENELTIAN}

Desain penelitian yang digunakan adalah analitik korelasional dengan pendekatan case control Pengambilan sampel menggunakan teknik consecutive sampling dengan responden penelitian berjumlah $12 \mathrm{ibu}$ hamil trimester III. Waktu pelaksanaan Maret-April 2019 di Kecamatan Semen Kabupaten Kediri, Jawa Timur, Indonesia. Variabel dalam penelitian adalah pengetahuan ibu hamil tentang tanda bahaya kehamilan dan pencapaian $\mathrm{K} 4$, hal ini dapat diketahui dengan melihat hasil kuisioner. Populasi sasaran penelitian adalah ibu hamil trimester III di Kecamatan Semen. Populasi sumber (populasi terjangkau) penelitian adalah ibu hamil trimester III di Kecamatan Semen. Sampel sebanyak 12 ibu hamil trimester III dengan teknik sampling jenuh yaitu dengan mengambil semua anggota populasi menjadi sampel. Teknik pengumpulan data menggunakan angket dan sumber data sekunder yaitu buku KIA. Data dianalisis menggunakan Analisis Bivariat dengan fisher exact menggunakan program SPSS.

\section{HASIL PENELITIAN}

Hasil penelitian menunjukkan karakteristik responden berdasarkan pendidikan terakhir, pekerjaan dan penghasilan per bulan yang tergambarkan pada tabel 1. Deskripsi variabel penelitian dijelaskan berdasarkan karakteristik, kriteria, frekuensi dan persentase (\%).

Tabel 1.Distribusi Responden menurut Pendidikan Terakhir, Pekerjaan dan Penghasilan per Bulan

\begin{tabular}{lcc}
\hline Data umum & Frekuensi & Persentase (\%) \\
\hline Pendidikan terakhir & 3 & 25 \\
SD & 4 & 33,33 \\
SMP & 3 & 25 \\
SMA & 1 & 8,33 \\
Tidak tamat SD & 1 & 8,33 \\
Perguruan Tinggi & & 0 \\
Pekerjaan & 0 & 0 \\
Wiraswasta & & \\
\hline
\end{tabular}




\begin{tabular}{lcc}
\hline Pegawai swasta & 0 & 0 \\
Pegawai negeri & 0 & 0 \\
Tidak bekerja & 7 & 58,33 \\
Lain-lain & 5 & 41,67 \\
Penghasilan per bulan & & \\
< Rp 999.000 & 10 & 83,33 \\
$\geq$ Rp 999.000 & 2 & 16,67 \\
\hline Sumber : Data Diolah,2016 & &
\end{tabular}

Tabel 1 menunjukkan bahwa dari 12 responden yang diteliti berdasarkan pendidikan terakhir, responden tertinggi adalah SMP yaitu $33,33 \%$ (4 orang), diikuti dengan SD sebesar 25\% (3 orang), SMA sebesar $25 \%$ (3 orang), tidak tamat SD 8,33\% (1 orang) dan Perguruan Tinggi $8,33 \%$ (1 orang). Untuk pekerjaan sebanyak $58,33 \%$ (7 orang) tidak bekerja dan sebanyak $41,67 \%$ (5 orang) mempunyai pekerjaan lain-lain yaitu petani, karyawan pabrik jamu dan GTT. Sedangkan berdasarkan penghasilan per bulan $83,33 \% \quad(10$ orang $)$ dengan penghasilan < Rp 999.000 dan 16,67\% (2 orang) dengan penghasilan $\geq \operatorname{Rp} 999.000$. Variabel dalam penelitian yaitu pengetahuan tentang tanda bahaya kehamilan dan pencapaian K4. Metode yang digunakan adalah uji chi-square. Hasil uji tergambar pada Tabel 2.

Tabel 2. Hasil Analisis Bivariat Hubungan Pengetahuan Ibu Hamil tentang Tanda Bahaya Kehamilan dengan Pencapaian K4

\begin{tabular}{lcccccccc}
\hline \multirow{2}{*}{ Pengetahuan } & \multicolumn{4}{c}{ Pencapaian K4 } & \multicolumn{2}{c}{ Jumlah } & \multirow{2}{*}{ Nilai $\boldsymbol{p}$} \\
\cline { 2 - 7 } & $\mathbf{N}$ & $\mathbf{\%}$ & $\mathbf{N}$ & $\boldsymbol{\%}$ & $\mathbf{N}$ & $\boldsymbol{\%}$ & \\
\hline Baik & 4 & 33,33 & 8 & 66,67 & 12 & 100 & 1 \\
Kurang & 0 & 0 & 0 & 0 & 0 & 0 & \\
\hline
\end{tabular}

Tabel 2 menunjukkan hasil uji bivariat dimana nilai $\mathrm{p}=1$ yang artinya tidak ada

\section{PEMBAHASAN}

Berdasarkan penelitian yang telah dilakukan didapatkan hasil bahwa ibu hamil trimester III di Desa Selopanggung Kecamatan Semen Kabupaten Kediri seluruhnya memiliki pengetahuan baik tentang tanda bahaya kehamilan yaitu sebanyak 12 responden (100\%). Berdasarkan penelitian Andaruni et al (2017),menyatakan bahwa pengetahuan dipengaruhi faktor pendidikan formal. hubungan ibu hamil tentang bahaya kehamilan dengan pencapaian K4

Pengetahuan sangat erat hubungannya dengan pendidikan, dimana diharapkan bahwa dengan pendidikan yang tinggi maka orang tersebut akan semakin luas pula pengetahuannya. Akan tetapi perlu ditekankan, bukan berarti seseorang yang berpendidikan rendah mutlak berpengetahuan rendah pula. Hal ini mengingat bahwa peningkatan pengetahuan tidak mutlak diperoleh dari 
pendidikan formal saja, akan tetapi dapat diperoleh melalui pendidikan non formal.

Hal ini sesuai dengan hasil penelitian yang menyatakan bahwa sebagian besar responden berpendidikan terakhir SMP. Selain itu karena ibu sebagian besar tidak bekerja atau menjadi ibu rumah tangga maka ibu mempunyai banyak waktu untuk mencari informasi mengenai tanda bahaya kehamilan dari berbagai sumber baik dari media massa seperti koran, majalah, leaflet, poster, buku KIA, maupun dari media elektronik seperti TV dan radio.

Peneliti juga berpendapat bahwa selain faktor internal seperti umur, pendidikan, dan pengalaman pribadi pengetahuan juga dipengaruhi oleh faktor eksternal yaitu lingkungan. Namun berdasarkan hasil penelitian yang telah dilakukan faktor lingkungan tidak begitu mempengaruhi tingginya pengetahuan responden tentang tanda bahaya kehamilan karena di daerah tersebut masih jarang dilakukan penyuluhan oleh tenaga kesehatan.

Berdasarkan penelitian yang telah dilakukan di Desa Selopanggung Kecamatan Semen Kabupaten Kediri diperoleh hasil bahwa ibu hamil trimester III sebanyak $67 \%$ dari 12 responden tidak mencapai K4 dan sebanyak 33\% yang dapat mencapai K4.

Rodiyatun et al (2018) menyatakan dalam penelitiannya bahwa beberapa faktor yang mempengaruhi cakupan program pemeriksaan kehamilan antara lain yaitu faktor geografis, persepsi, perilaku dalam bentuk pengetahuan, perilaku dalam bentuk sikap, perilaku dalam bentuk tindakan dan perubahan perilaku. Nur et al (2019) menyebutkan dalam penelitiannya bahwa faktor yang mempengaruhi tercapai tidaknya $\mathrm{K} 4$ ibu hamil yaitu latar belakang sosial ekonomi, sosial budaya dan lingkungan hidup setiap keluarga yang tidak semuanya sama.

Faktor yang mempengaruhi rendahnya pencapaian $\mathrm{K} 4$ adalah faktor sosial ekonomi. Sebagian besar warga Selopanggung bekerja sebagai petani dan berpenghasilan di bawah UMR sehingga membuat ibu merasa keberatan untuk memeriksakan kehamilannya. Kemudian sosial budaya masyarakat setempat yang masih mempercayakan proses persalinannya pada dukun. Dengan adanya dukun maka ibu berfikir bahwa tidak perlu memeriksakan kehamilannya asalkan kelak pada saat melahirkan proses persalinannya berjalan dengan lancar (Hanna, 2016).

Selain itu faktor geografis juga mempengaruhi rendahnya pencapaian K4 . Berdasarkan penelitian yang telah dilakukan, letak geografis di Desa Selopanggung Kecamatan Semen Kabupaten Kediri berada pada dataran tinggi dan luas (Riyanti N, 2018). Jarak antara rumah warga dengan tenaga kesehatan, misalnya bidan atau Puskesmas relatif jauh dan medan yang dilewati sangat sulit sehingga memungkinkan kontak ibu hamil dengan petugas kesehatan menjadi jarang dan menyebabkan rendahnya pencapaian K4. Faktor dari tenaga kesehatan juga dapat mempengaruhi pencapaian K4. Jika ibu tidak memeriksakan kehamilannya maka tenaga kesehatan yang harus lebih aktif misal dengan melaksanakan kunjungan rumah ibu hamil.Dukungan keluarga juga penting dalam pencapaian K4. Sebagian besar warga selopanggung bekerja sebagai petani dan menghabiskan waktunya di sawah.Mereka lebih mementingkan dalam mencari nafkah 
sehingga kebutuhan kesehatan menjadi terabaikan.

Berdasarkan hasil perhitungan didapatkan bahwa tidak ada hubungan pengetahuan ibu hamil tentang tanda bahaya kehamilan dengan pencapaian K4. Hal ini disebabkan karena nilai $p>$ nilai $\alpha$ atau apabila dilihat besaran angka dapat dilihat bahwa $1>0.05$ sehingga memiliki arti bahwa $\mathrm{H}_{0}$ diterima. Berdasarkan hipotesis penelitian dapat diartikan bahwa tidak ada hubungan antara pengetahuan ibu hamil tentang tanda bahaya kehamilan dengan pencapaian K4 (Tasliah, 2017 dan Hidayah, 2018).

Hasil yang diperoleh berdasarkan perhitungan menggunakan uji $C h i$ Kuadrat satu sampel, didapatkan bahwa $\chi^{2}$ hitung sebesar $1,34<\chi^{2}$ tabel sebesar 6,635 , sehingga peluang ibu hamil yang berpengetahuan baik dapat mencapai K4 atau tidak dapat mencapai $\mathrm{K} 4$ adalah sama.

Berdasarkan hasil tabulasi pengetahuan dan pencapaian $\mathrm{K} 4$ terdapat 4 ibu hamil dengan pengetahuan baik tidak dapat mencapai K4 karena pada saat trimester 1 tidak melakukan pemeriksaan kehamilan pada petugas kesehatan. Dari 4 responden tersebut terdapat 3 responden mempunyai pengetahuan yang salah tentang tekanan darah tinggi pada kehamilan. Selain 4 responden tersebut ternyata sebagian besar ibu hamil kurang mengetahui tentang tanda bahaya kehamilan yang mengarah pada tekanan darah tinggi pada kehamilan.

Berdasarkan data yang diperoleh dari penelitian pada dasarnya pengetahuan dapat mempengaruhi pencapaian dari suatu program. Namun dalam hal ini pengetahuan bukan merupakan faktor yang dominan dalam pencapaian $\mathrm{K} 4$ sehingga ibu yang berpengetahuan baik belum tentu dapat mencapai $\mathrm{K} 4$ begitu juga sebaliknya ibu yang mempunyai pengetahuan kurang belum tentu tidak dapat mencapai K4. Hal tersebut sesuai dengan hasil penelitian yang dilakukan Artika (2016) dan Mara (2018) bahwa faktor yang mempengaruhi tercapai tidaknya K4 ibu hamil yaitu latar belakang sosial ekonomi, sosial budaya dan lingkungan hidup setiap keluarga yang tidak semuanya sama.

\section{KESIMPULAN DAN SARAN}

Dari hasil penelitian yang dilakukan di Desa Selopanggung Kecamatan Semen Kabupaten Kediri, dapat ditarik kesimpulan yaitu; Pengetahuan tentang tanda bahaya kehamilan seluruhnya memiliki pengetahuan baik, pencapaian K4 di desa Selopanggung sebagian besar tidak tercapai danTidak ada hubungan antara pengetahuan ibu hamil tentang tanda bahaya kehamilan dengan pencapaian K4.

\section{DAFTAR RUJUKAN}

Andaruni NQR, Catur EP dan Cahaya IL. (2017). Gambaran Tingkat Pengetahuan Ibu Hamil Tentang Tanda-tanda Bahaya Kehamilan Trimester I di Puskesmas Karang Pule. Midwifery Journal. Volume 2 (2).

Artika. (2016). Asuhan Kebidanan Masa Kehamilan. Yogyakarta: Graha Ilmu.

Fadiar N I dan Titin U. (2018). Pengetahuan Tanda Bahaya Kehamilan Dan Perilaku Perawatan Kehamilan Pada Ibu Hamil Trimester III. Jurnal Keperawatan Indonesia, Vol. 16 (1) : 18-24. 
Hanna. (2016). Timing of First Antenatal Care Visit and Its Associated Factors Among Pregnant Women Attending Public Health Facilities in Addis Ababa Ethiopia.

Hidayat, A Aziz. (2016). Metode Penelitian Kebidanan Dan Teknik Analisis Data. Salemba Medika, Jakarta.

Kementerian Kesehatan RI, (2016).

Marniyati L, Irsan S dan Bambang BS. (2016). Pelayanan Antenatal Berkualitas Dalam Meningkatkan Deteksi Risiko Tinggi pada Ibu Hamil oleh Tenaga Kesehatan di Puskesmas Sako, Sosial, Sei Baung dan Sei Selincah di Kota Palembang. Jurnal Kedokteran dan Kesehatan. Volume 3 (1).

Maternity dan Putri. (2017). Asuhan Kebidanan Komunitas Disesuaikan dengan Rencana Pembelajaran Kebidanan. Yogyakarta : ANDI.

Nugroho, Hipson dan Rozakhan. (2017). Patologi Kebidanan. Yogyakarta: Nuha Medika.

Nur Yulia M, Septaneliy dan Lasmi Lestari. (2019). Faktor yang Berhubungan Dengan Kunjungan Antenatal Care. Jurnal Kesehatan. Volume 10 (2).

Nuraisya, W. (2018). Deteksi Risiko Tinggi Kehamilan Pda Pelayanan ANC Terpadu di Puskesmas Bendo Kabupaten Kediri. Jurnal Kesehatan Andalas. Volume 7(2).
Dinas Kesehatan Provinsi Jawa Timur. (2017). Profil Kesehatan Jawa Timur.

Ritsma A dan Sumiatun. (2018). Pengaruh Kehamilan Terhadap Frekuensi Kekambuhan Pada Ibu Hamil Trimester I, II dan III. Journal of Nursing Care \& Biomolecular. Volume 2 (2).

Riyanti, N. 2018. Faktor Yang Berhubungan Dengan Kunjungan K4 Pada Ibu Hamil. Jurnal Ilmiah Multi Science. Vol 9 (2).

Rodiyatun, Anis NL dan Vicky AR. (2018). Pengaruh Budaya Patriarki Terhadap Keteraturan Pemeriksaan Kehamilan Pada Ibu Hamil di Wilayah Puskesmas Bangkalan. Embrio, Jurnal Kebidanan. Vol X (1).

Rukiyah, Ai Yeyeh. (2014). Asuhan Kebidanan I (Kehamilan). Cetakan Pertama Jakarta: Trans Info Media.

Tasliah. (2017). Faktor-faktor yang Berhubungan Dengan Kunjungan Antenatal Care Pada Ibu Hamil di Wilayah Kerja Candilama Kota Semarang.

World Health Organization. (2016). The world health report: Make every mother \& child count. Geneve: WHO Press. Diperoleh dari http:// www.who.int/mediacentre/factsheet s/fs348/en/. Diakses pada 22 Januari 2020. 